\title{
Discovery of Novel Diarylamide $N$-Containing Heterocyclic Derivatives as New Tubulin Polymerization Inhibitors with Anti-Cancer Activity
}

\author{
Xu Liu ${ }^{1,+}$, Xiao-Jing Pang ${ }^{1,+}$, Yuan Liu ${ }^{1}$, Wen-Bo Liu ${ }^{1}$, Yin-Ru Li ${ }^{2}$, Guang-Xi Yu ${ }^{1}$, Yan-Bing Zhang ${ }^{1}$, Jian Song ${ }^{1, *}$ \\ and Sai-Yang Zhang ${ }^{1,2, * \mathbb{D}}$ \\ 1 Key Laboratory of Advanced Drug Preparation Technologies (Ministry of Education), \\ Institute of Drug Discovery \& Development, School of Pharmaceutical Sciences, Zhengzhou University, \\ Zhengzhou 450001, China; 1x012496@163.com (X.L.); summer_pxj@163.com (X.-J.P.); \\ liuyuan9720@163.com (Y.L.); 17698567571@163.com (W.-B.L.); ygx19990110@126.com (G.-X.Y.); \\ zhangyb@zzu.edu.cn (Y.-B.Z.) \\ 2 School of Basic Medical Sciences, Zhengzhou University, Zhengzhou, 450001, China; 17603868158@163.com \\ * Correspondence: mumuandzz@163.com (J.S.); saiyangz@zzu.edu.cn (S.-Y.Z.) \\ + These authors contributed equally to this work.
}

\section{check for} updates

Citation: Liu, X.; Pang, X.-J.; Liu, Y.; Liu, W.-B.; Li, Y.-R.; Yu, G.-X.; Zhang, Y.-B.; Song, J.; Zhang, S.-Y. Discovery of Novel Diarylamide $\mathrm{N}$-Containing Heterocyclic Derivatives as New Tubulin Polymerization Inhibitors with Anti-Cancer Activity. Molecules 2021, 26, 4047. https://doi.org/ $10.3390 /$ molecules 26134047

Academic Editor: Maria Emília de Sousa

Received: 8 May 2021

Accepted: 29 June 2021

Published: 2 July 2021

Publisher's Note: MDPI stays neutral with regard to jurisdictional claims in published maps and institutional affiliations.

Copyright: (c) 2021 by the authors. Licensee MDPI, Basel, Switzerland. This article is an open access article distributed under the terms and conditions of the Creative Commons Attribution (CC BY) license (https:// creativecommons.org/licenses/by/ $4.0 /)$.

\begin{abstract}
Tubulin has been regarded as an attractive and successful molecular target in cancer therapy and drug discovery. Vicinal diaryl is a simple scaffold found in many colchicine site tubulin inhibitors, which is also an important pharmacophoric point of tubulin binding and anti-cancer activity. As the continuation of our research work on colchicine binding site tubulin inhibitors, we designed and synthesized a series of diarylamide $N$-containing heterocyclic derivatives by the combination of vicinal diaryl core and $N$-containing heterocyclic skeletons into one hybrid though proper linkers. Among of these compounds, compound $\mathbf{1 5 b}$ containing a 5-methoxyindole group exhibited the most potent inhibitory activity against the tested three human cancer cell lines (MGC803, PC-3 and EC-109) with $\mathrm{IC}_{50}$ values of $1.56 \mu \mathrm{M}, 3.56 \mu \mathrm{M}$ and $14.5 \mu \mathrm{M}$, respectively. Besides, the SARs of these compounds were preliminarily studied and summarized. The most active compound $\mathbf{1 5 b}$ produced the inhibition of tubulin polymerization in a dose-dependent manner and caused microtubule network disruption in MGC-803 cells. Therefore, compound $\mathbf{1 5 b}$ was identified as a novel tubulin polymerization inhibitor targeting the colchicine binding site. In addition, the results of molecular docking also suggested compound $\mathbf{1 5 b}$ could tightly bind into the colchicine binding site of $\beta$-tubulin.
\end{abstract}

Keywords: tubulin; CA-4; vicinal diaryl; $N$-containing heterocyclics; anti-proliferative activity; colchicine binding site

\section{Introduction}

Tubulin is an important component of the cytoskeleton and plays a vital role in the process of maintaining normal cell formation, cell mitosis, signal transduction and material transportation [1,2]. Tubulin has been regarded as an attractive and successful molecular target in cancer therapy and drug discovery [3]. Tubulin-targeting agents with excellent anti-cancer activity such as paclitaxel/Taxol, vincristine and vinblastine have been successfully used in clinical treatment [4]. However, owing to the poor water solubility, drug resistance or side effects of clinical used tubulin inhibitors [5-7], it is necessary to develop novel tubulin inhibitors [6]. However, colchicine site tubulin inhibitors have received extraordinary attention in the recent years, which could largely overcome the above drawbacks and have more therapeutic advantages over other binding sites tubulin inhibitors [8,9]. In addition, no colchicine site tubulin inhibitors have not been approved for clinical use; therefore, it is necessary to develop novel colchicine site tubulin inhibitors. 
Vicinal diaryl is a simple scaffold found in many colchicine site tubulin inhibitors, which is also an important pharmacophoric point of tubulin binding and anti-cancer activity [10-13]. Natural colchicine site tubulin inhibitor combretastatin A-4 (CA-4) is a 1,2diarylethylene analog, which exhibits potent inhibitory potency against many cancer cells including multidrug resistant cancer cells and could effectively inhibit the polymerization of tubulin [14]. However, due to the poor water solubility, low bioavailability and unstable cis double bond of CA-4 [12,15], its clinical application is limited; therefore, clinical work with CA-4 was carried out with the corresponding water-soluble phosphate prodrug salt (CA-4P) [16]. Therefore, many groups have reported novel colchicine site tubulin inhibitors with vicinal diaryl cores base on the structural optimizations of CA-4 [17-25]. Cushman et al. reported a novel tubulin inhibitor benzyl aniline $\mathbf{1}$ in which the olefinic bridge of the CA-4 was replaced by an aminomethylene hydrochloride moiety. Compound 1 retained significant anti-proliferative activity and inhibitory potency of tubulin polymerization [23] Romagnoli et al. replaced the usual ethylene bridge of the led CA-4 with a five membered heterocyclic ring to obtain 1,5-disubstituted 1,2,4-triazole 2. Compound 2 exhibited potent inhibitory effect on tubulin polymerization $\left(\mathrm{IC}_{50}=2.3 \mu \mathrm{M}\right)$, and significantly suppressed the growth of human cancer cells at nano-molar levels [24]. Meegan's group reported a class of diaryl- $\beta$-lactam derivatives which contained the $\beta$-lactam ring system in place of the ethylene bridge of the led CA-4 [25]. Compound 3 displayed sub nano-molar inhibitory activity against breast cancer cells MCF-7 and MDA-MB-231 ( $\mathrm{IC}_{50}=34$ and $78 \mathrm{nM}$, respectively) together with significant inhibition of tubulin polymerization (Figure 1). Therefore, tubulin inhibitors bearing the vicinal diaryl moiety may be favorable for the interactions with tubulin.<smiles>COc1ccc(/C=C\c2cc(OC)c(OC)c(OC)c2)cc1O</smiles>

Combretastatin A-4<smiles>COc1ccc(NCc2cc(OC)c(OC)c(OC)c2)cc1</smiles>

1<smiles>COc1ccc(-c2ncnn2-c2cc(OC)c(OC)c(OC)c2)cc1</smiles>

2

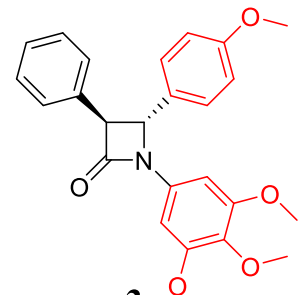

3

Figure 1. Structures of CA-4 and CA-4 analogs as tubulin inhibitors.

$\mathrm{N}$-containing heterocyclic skeleton is one of most attractive frameworks in bioactive compounds with strong pharmacological significance [26], especially the anti-cancer ability. For example, indole [27-32], indoline [33-35] and tetrahydroquinoline derivatives [36-38] have also been used to design novel colchicine binding site tubulin inhibitors with potent anti-cancer activity. Chalcone indole derivative 4 potently inhibited cancer cell growth with $\mathrm{IC}_{50}$ values ranging from 0.22 to $1.80 \mu \mathrm{M}$ [30]. Compound 4 induced cell cycle arrest in G2/M phase and effectively inhibited the polymerization of tubulin. Quinoline-indole derivative 5 as an anti-tubulin agent targeting the colchicine binding site showed effective inhibition effect against tested cancer cell lines with $\mathrm{IC}_{50}$ values ranging from 2 to $11 \mathrm{nM}$ together with significant in vitro inhibition of tubulin polymerization $\left(\mathrm{IC}_{50}=2.09 \mu \mathrm{M}\right)$ [31]. Benzimidazole-indole derivative 6 exhibited potent inhibitory effects on the growth of cancer cells with an average $\mathrm{IC}_{50}$ value of $50 \mathrm{nM}$ together with significant in vitro inhibition of tubulin polymerization $\left(\mathrm{IC}_{50}=2.52 \mu \mathrm{M}\right)$ [32]. The 7-Aroyl-aminoindoline-1-sulfonamide 7 potently inhibited the tubulin polymerization $\left(\mathrm{IC}_{50}=1.1 \mu \mathrm{M}\right)$ by binding to colchicine binding site. Compound 7 effectively suppressed the growth of KB, MKN45, H460, HT29 and TSGH cells with $\mathrm{IC}_{50}$ values ranging from $8.6 \mathrm{nM}$ to $10.8 \mathrm{nM}$ [35]. Tetrahydroquinoline-pyrimidine [38] showed strong anti-proliferative activity $\left(\mathrm{IC}_{50}\right.$ values ranging from 5.6 to $18.3 \mathrm{nM}$ ) via tubulin polymerization inhibition and potently inhibited tumor growth in an A375 melanoma xenograft model (Figure 2). 


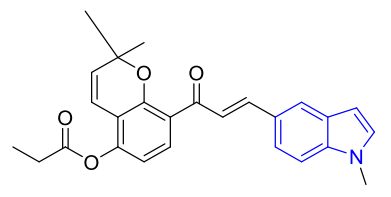

4

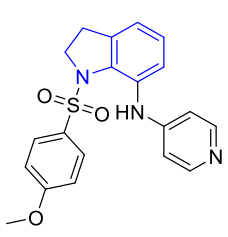

7

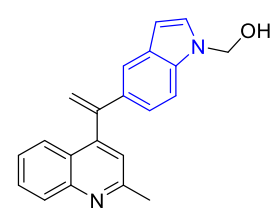

5

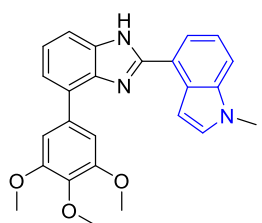

6

Figure 2. Structures of $\mathrm{N}$-containing heterocyclic derivatives as tubulin inhibitors.

Based on the above findings and as the continuation of our group work on colchicine binding site tubulin inhibitors, we designed and synthesized a series of diarylamide $\mathrm{N}$-containing heterocyclic derivatives by the combination of vicinal diaryl core and $\mathrm{N}$ containing heterocyclic skeleton into one hybrid though proper linkers (Figure 3). Among of these compounds, compound $\mathbf{1 5 b}$ was identified as a tubulin inhibitor with potent anti-cancer activity.

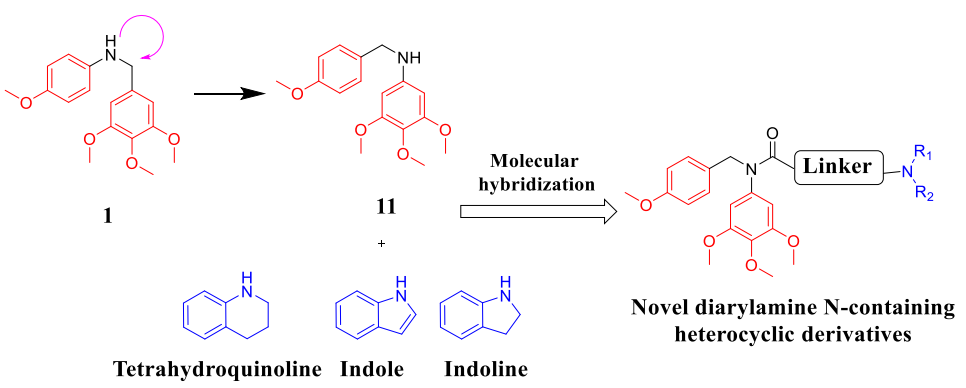

Figure 3. Design of diarylamide $N$-containing heterocyclic derivatives in this work.

\section{Results and Discussion}

\subsection{Chemistry}

As shown in Scheme 1, all the target compounds 15a-15h and 19a-19g were synthesized by starting from commercially available 4-methoxybenzylchloride $\mathbf{9}$ and 3,4,5-trimethoxyaniline 10. The 4-Methoxybenzylchloride 9 reacted with the 3,4,5-trimethoxyaniline 10 in the presence of $\mathrm{K}_{2} \mathrm{CO}_{3}$ in DMF to give compound 11. Then compound 11 reacted with chloroacetyl chloride to afford compound 13 in DMF. Substitution reactions between compound 13 with indoles, indolines or tetrahydroquinolines 14 in the presence of $\mathrm{K}_{2} \mathrm{CO}_{3}$ in acetonitrile gave compounds $\mathbf{1 5 a}-\mathbf{h}$. In the synthesis of another series of compounds, compounds $\mathbf{1 4}$ reacted with 3-bromopropyne 16 in the presence of $\mathrm{K}_{2} \mathrm{CO}_{3}$ in acetonitrile to obtain compound 17. Substitution reaction between compound 15 with sodium azide in the presence of $\mathrm{K}_{2} \mathrm{CO}_{3}$ in acetonitrile gave compound 18. Then click reactions between compound $\mathbf{1 7}$ with $\mathbf{1 8}$ in the presence of $\mathrm{CuSO}_{4}$ and sodium ascorbate in $\mathrm{THF} / \mathrm{H}_{2} \mathrm{O}(1: 1)$ gave compounds 19a-e. Finally, all the target compounds were fully characterized by NMR and HMRS which was showed in the Supplementary Materials. 


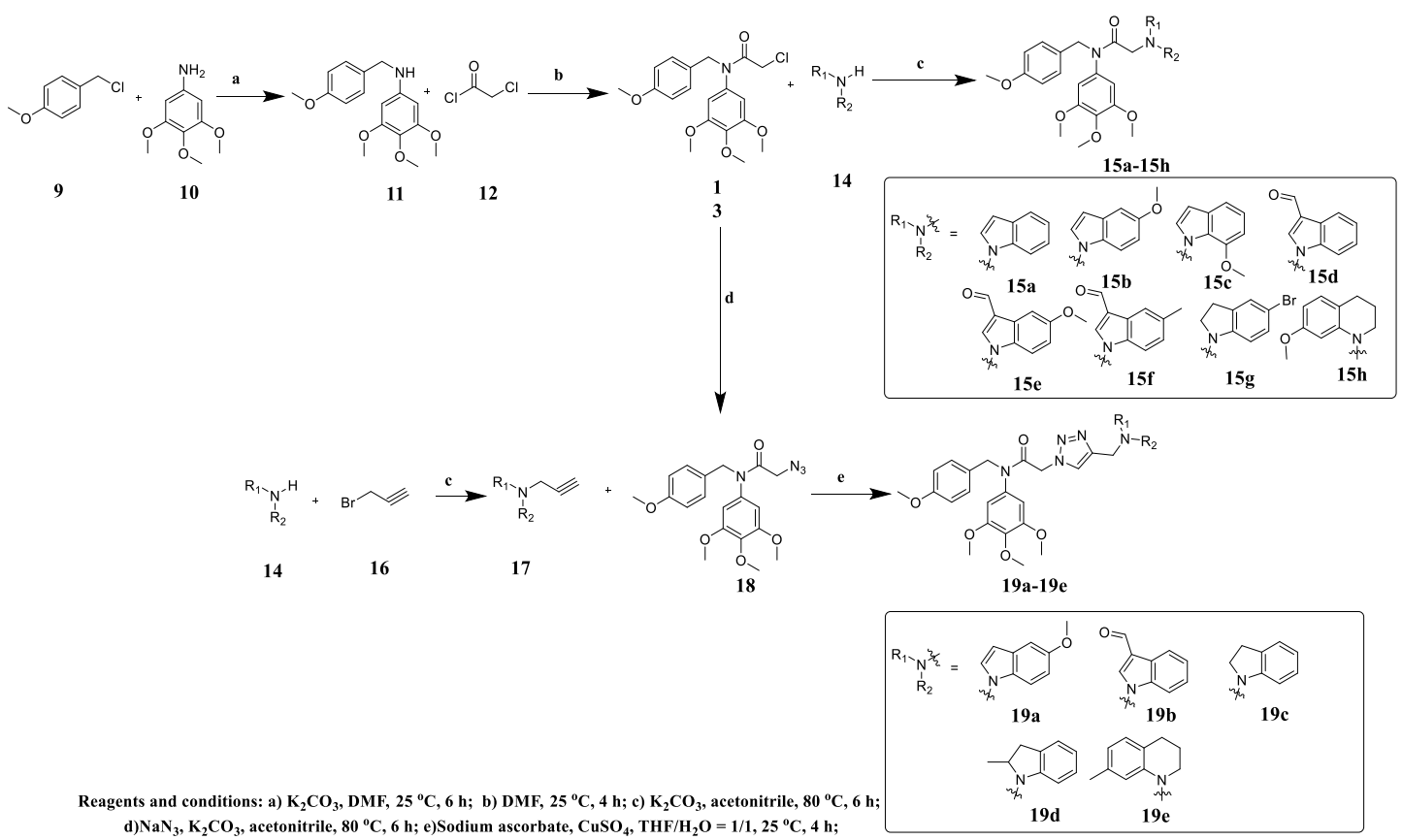

Scheme 1. Synthetic routes of diarylamide $N$-containing heterocyclic derivatives.

\subsection{Anti-proliferative Activity and Structure Activity Relationships}

According to the latest cancer data in China [39] and the actual situation of our laboratory, the in vitro anti-proliferative activity of new target compounds $\mathbf{1 5} \mathbf{a}-\mathbf{h}$ and 19a-e were evaluated against MGC-803 cell line (human gastric cancer), HCT-116 cell line (human colon cancer) and PC-3 cell line (human prostate cancer) using MTT assays with the well characterized tubulin inhibitor colchicine was used as a positive control. The following Tables 1 and 2 depicted the results of in vitro anti-proliferative activity.

Table 1. In vitro anti-proliferative activity of compounds $15 \mathbf{a}-\mathbf{h}$ against MGC-803, PC-3 and EC-109 cells.<smiles>[R]N([R])CC(=O)N(Cc1ccc(OC)cc1)c1cc(OC)c(OC)c(OC)c1</smiles>

\begin{tabular}{cccc}
\hline \multirow{2}{*}{ Compounds } & \multicolumn{3}{c}{ IC $_{\mathbf{5 0}}(\boldsymbol{\mu M})^{\mathbf{a}}$} \\
\cline { 2 - 4 } & MGC-803 & PC-3 & EC-109 \\
\hline 15a & $1.88 \pm 0.58$ & $6.27 \pm 0.19$ & $19.61 \pm 1.07$ \\
$\mathbf{1 5 b}$ & $1.56 \pm 0.58$ & $3.56 \pm 0.07$ & $14.5 \pm 0.68$ \\
$\mathbf{1 5 c}$ & $6.25 \pm 2.73$ & $12.03 \pm 1.04$ & $24.61 \pm 2.07$ \\
$\mathbf{1 5 d}$ & $20.99 \pm 1.32$ & $18.09 \pm 1.28$ & $54.07 \pm 2.83$ \\
$\mathbf{1 5}$ & $10.83 \pm 6.58$ & $29.78 \pm 2.51$ & $47.72 \pm 2.49$ \\
$\mathbf{1 5 f}$ & $11.89 \pm 6.15$ & $19.83 \pm 1.47$ & $46.81 \pm 2.89$ \\
$\mathbf{1 5 g}$ & $9.93 \pm 6.83$ & $16.29 \pm 1.01$ & $31.87 \pm 42.6$ \\
$\mathbf{1 5 h}$ & $10.41 \pm 3.60$ & $22.56 \pm 1.54$ & $21.71 \pm 1.49$ \\
Colchicine & $0.18 \pm 0.02$ & $0.23 \pm 0.08$ & $0.32 \pm 0.12$ \\
\hline
\end{tabular}

${ }^{a}$ In vitro anti-proliferative activity was assayed by exposure for $48 \mathrm{~h}$. 
Table 2. In vitro anti-proliferative activity of compounds 19a-e against MGC-803, PC-3 and EC-109 cells.

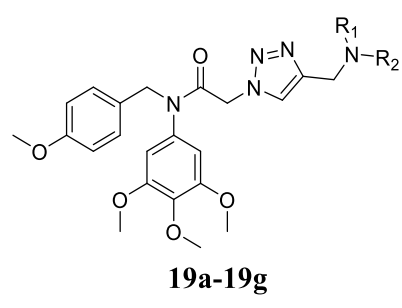

\begin{tabular}{cccc}
\hline \multirow{2}{*}{ Compounds } & \multicolumn{3}{c}{ IC $_{\mathbf{5 0}}(\boldsymbol{\mu M} \mathbf{M})^{\mathbf{a}}$} \\
\cline { 2 - 4 } & MGC-803 & PC-3 & EC-109 \\
\hline 19a & $6.38 \pm 0.83$ & $10.28 \pm 1.03$ & $21.59 \pm 1.84$ \\
19b & $21.89 \pm 1.59$ & $42.19 \pm 2.03$ & $52.07 \pm 0.51$ \\
19c & $47.75 \pm 2.88$ & $68.25 \pm 3.28$ & $14.52 \pm 0.28$ \\
19d & $30.69 \pm 2.16$ & $>80$ & $>80$ \\
19e & $40.57 \pm 2.34$ & $>80$ & $72.12 \pm 4.66$ \\
Colchicine & $0.18 \pm 0.02$ & $0.23 \pm 0.08$ & $0.32 \pm 0.12$ \\
\hline
\end{tabular}

${ }^{a}$ In vitro anti-proliferative activity was assayed by exposure for $48 \mathrm{~h}$.

To explore the relationships between chemical groups and anti-proliferative activity, compounds 15a-h were designed and synthesized. Representative chemical features of compounds $\mathbf{1 5} \mathbf{a}-\mathbf{h}$ are that different moiety such as indoles, indolines and tetrahydroquinoline, which are linked to diarylamide core through an alkyl linker. Most of these compounds exhibited certain anti-proliferative potency against three human cancer cell lines. Particularly, compound $\mathbf{1 5 b}$ exhibited the most potent inhibitory activity against the tested three human cancer cell lines (MGC-803, PC-3 and EC-109) with $\mathrm{IC}_{50}$ values of $1.56 \mu \mathrm{M}, 3.56 \mu \mathrm{M}$ and $14.5 \mu \mathrm{M}$, respectively. The anti-proliferative activity of the compounds varies with its substituent moieties. Compared compounds 15a with 15g and 15h, compounds with an indole group exhibited better anti-proliferative potency than compounds $15 \mathrm{~g}$ and $15 \mathrm{~h}$ with indoline and tetrahydroquinoline. Similarly, the substituent groups of indole group were also important for anti-proliferative activity. When indole ring is substituted by methoxy group at 5-position, the activity of the compound is the best. However, the anti-proliferative activity of compound was less potent when there was an aldehyde group at the 3-position of indole ring (compounds 15d, 15e and 15f) than that of compounds $\mathbf{1 5 a}$ and $\mathbf{1 5 b}$. In addition, most of compound were more sensitive to MGC-803 cells than to PC-3 and EC-109 cells. These inhibitory results suggested that substituent moieties of compounds exhibited significant effects on anti-proliferative efficacy.

The 1,2,3-Triazole was usually used as a potentially pharmacological linker and fragment to design novel anti-cancer hybrids in medicinal chemistry [40]. Therefore, compounds 19a-e were designed and synthesized by replacing the alkyl linker with a 1,2,3-triazole linker to explore the effects of linkers on activity further. As shown in Table 2, the inhibitory potency of compounds 19a-e was decreased when the alkyl linker was replaced by a 1,2,3-triazole linker (compounds 19 a vs. $15 b$ and $19 b$ vs. 15d), indicating that the 1,2,3-triazole linker could not improve the inhibitory potency for the diarylamide indole derivatives. Besides, compound $\mathbf{1 9 b}$ with a 5 -methoxyindole group also exhibited the strongest inhibitory activity in this series compounds, which was consist with that of compound 15b. Most of this series compounds were also more sensitive to MGC-803 cells than to PC-3 and EC-109 cells.

Based on the above inhibitory activity results of compounds $15 \mathbf{a}-\mathbf{h}$ and $19 \mathbf{a}-\mathbf{e}$, the structure-activity relationships were summarized. We concluded that nitrogen heterocycle played a significant role in anti-proliferative activity (indole $>$ indoline $>$ tetrahydroquinoline). Proper liner is beneficial to maintain anti-proliferative activity (alkyl linker $>$ 1,2,3-triazole linker). 


\subsection{Compound 15b Inhibited Tubulin Polymerization}

As its target protein, inhibitory effects on tubulin polymerization of compound $\mathbf{1 5 b}$ was first to be detected. Cell free tubulin polymerization assay was performed to evaluate anti-tubulin polymerization activity of compound $\mathbf{1 5 b}$ at different concentrations with the famous tubulin inhibitors colchicine and paclitaxel. As shown in Figure 4A, when tubulin was incubated with $\mathbf{1 5 b}(10 \mu \mathrm{M}$ and $20 \mu \mathrm{M})$, the increased tendency of the fluorescence intensity was obviously slowed down with a similar action to that of colchicine, which indicated that compound $\mathbf{1 5 b}$ inhibited tubulin polymerization in a dose-dependent manner. However, the inhibitory activity of compound $\mathbf{1 5 b}$ on tubulin polymerization is less potent than that of colchicine, which is also consistent with results the anti-proliferative activity. Next, to investigate the effects to microtubules, compound $15 \mathrm{~b}$ was selected to do immunofluorescence assay by staining tubulin. As shown in Figure 4B, cells' morphologies were captured with immunofluorescence (IF) assay. MGC-803 cells treated with $\mathbf{1 5 b}$ at various concentrations $(0.5 \mu \mathrm{M}, 1 \mu \mathrm{M}$, and $2 \mu \mathrm{M})$ for $24 \mathrm{~h}$ resulted in disruption of microtubule networks, while the tubulins were polymerized to micro-tubes in control group. These results indicated that compound $\mathbf{1 5 b}$ produced the inhibition of tubulin polymerization a dose-dependent manner and caused microtubule network disruption in MGC-803 cells.

A

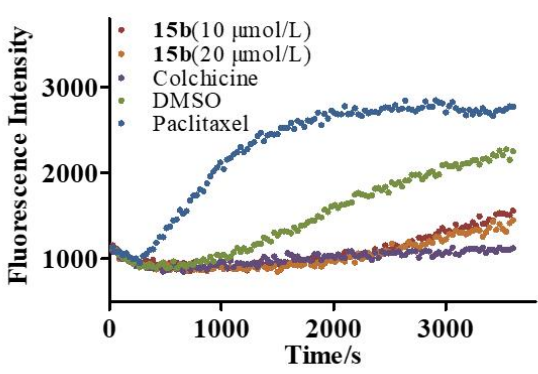

Control

$0.5 \mu \mathrm{mol} / \mathrm{L}$

$2 \mu \mathrm{mol} / \mathrm{L}$

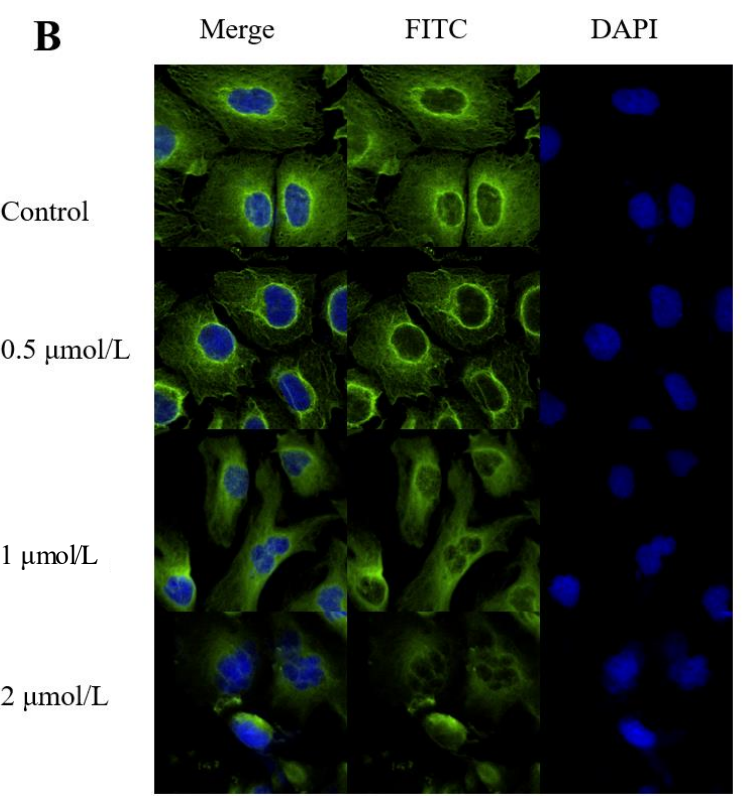

Figure 4. Compound 15b inhibited tubulin polymerization. (A). Cell Free Tubulin Polymerization Assay, concentrations of Paclitaxel and Colchicine were $3.0 \mu \mathrm{mol} / \mathrm{L} ;(\mathbf{B}) . \beta$-tubulin (green) nucleus (blue) in MGC-803 cells. Cells were incubated with $0.5,1$ and $2 \mu \mathrm{M}$ compound $\mathbf{1 5 b}$ for $24 \mathrm{~h}$.

\subsection{Compound 15b Bound to the Colchicine Site of $\beta$-tubulin and Molecular Docking Study}

The $N, N^{\prime}$-ethylenebis (iodoacetamide) (EBI) assay is usually used to test the binding ability of small molecules to $\beta$-tubulin at colchicine binding sites. Therefore, whether compound $15 \mathrm{~b}$ acts on the colchicine binding site of tubulin was next to detected. As shown in Figure 5A, the results showed that with the increase of the concentration of compound 15b, $\beta$-tubulin adducts decreased gradually, which indicated that compound $\mathbf{1 5 b}$ directly bound to the colchicine site of $\beta$-tubulin. The Cellular Thermo Shift Assay (CTSA) can detect the direct interaction between compound and proteins. As shown in Figure $5 \mathrm{C}, \mathrm{D}$, compound $\mathbf{1 5 b}(100 \mu \mathrm{M})$ obviously accelerated the decrease of $\beta$-tubulin. These results suggested that compound $\mathbf{1 5 b}$ directly interacted with $\beta$-tubulin and targeted the colchicine binding site. 


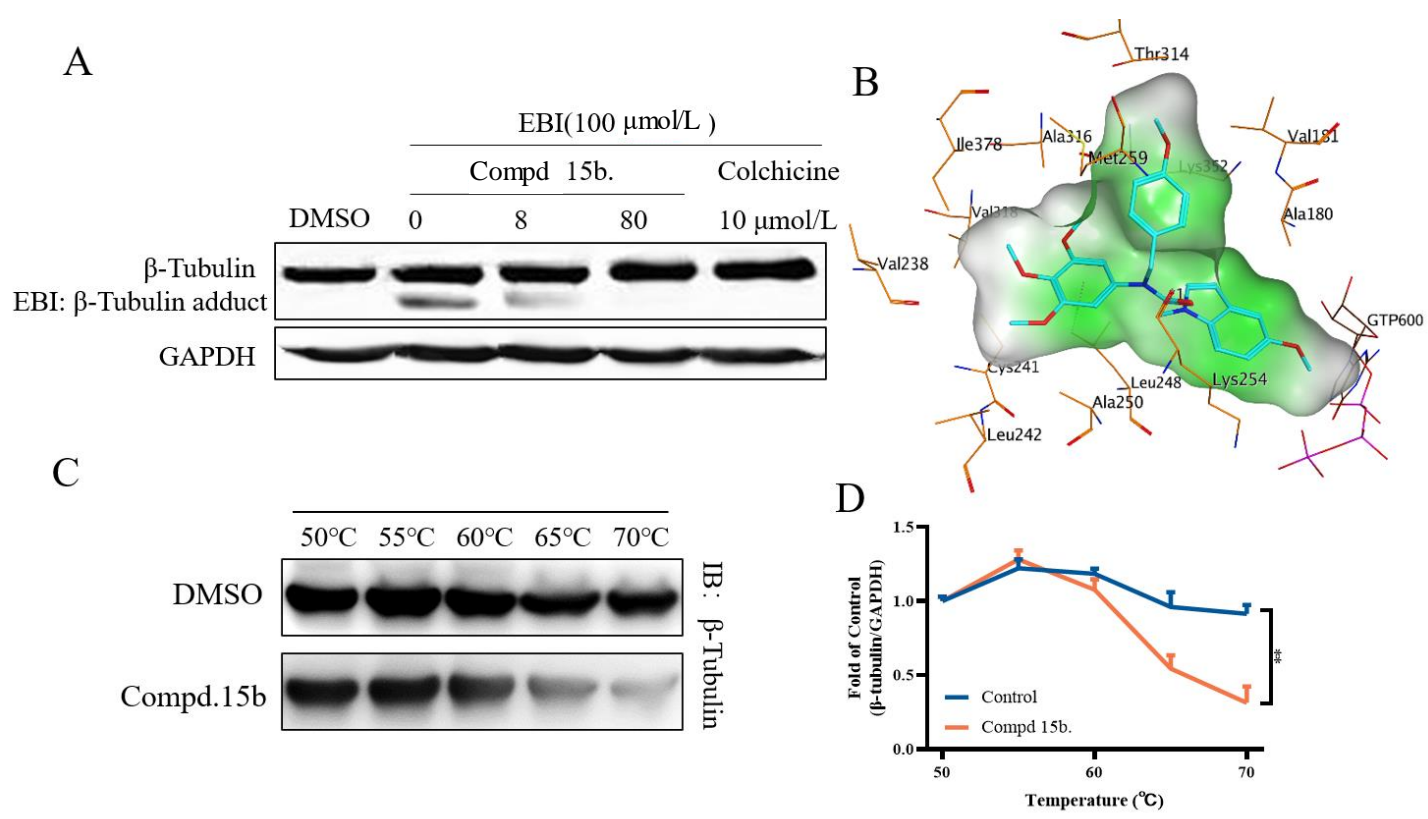

Figure 5. Compound $\mathbf{1 5 b}$ bind to the colchicine site. (A) EBI competition assay, cells were incubated with compound/colchicine and EBI; (B) The docking of the colchicine binding site and compound 15b; (C,D) The Cellular Thermo Shift Assay. Cell Lysates were incubated with or without compound $\mathbf{1 5 b}$. Then were incubated in different temperatures.

Compound $\mathbf{1 5 b}$ displayed inhibitory effects on tubulin polymerization in the screening above, and we then selected it as the optimized compound for the molecular docking studies by Autodock software. To investigate the binding site of compound $\mathbf{1 5 b}$ with the tubulin-microtubule system, PDB code $1 \mathrm{SA} 0$ was selected. The docking results were listed in Figure 5B, trimethoxyphenyl is located in a hydrophobic pocket consist of Val238, Cys241, Leu242, Leu248, Leu259, Ala316, Val319, Ile378 and other residues, and forms a strong hydrophobic interaction with this pocket. 4-methoxyphenyl occupies another hydrophobic pocket and forms extensive hydrophobic interactions with Val191, Met259, Thr314, Ala316, Lys352 and other residues. In addition, the substituted methoxy group on the indole ring faces the vicinity of the electronegative phosphate of the GTP molecule, forming a favorable electrostatic match with this region. At the same time, it also forms a certain hydrophobic effect with residues such as Ala190, Leu248 and Lys254. The above results indicated that compound $\mathbf{1 5 b}$ bound tightly to the colchicine binding site of $\beta$-tubulin and showed polymerization inhibitory activity on $\beta$-tubulin.

\section{Materials and Methods}

All the chemical reagents were purchased from commercial suppliers (Energy chemical Company, Shanghai, China and Zhengzhou HeQi Company, Zhengzhou, China). Melting points were determined on an X-5 micromelting apparatus. NMR spectra data was recorded with a Bruker spectrometer. HRMS spectra data was obtained using a Waters Micromass spectrometer. HPLC conditions: injection volume: $10 \mu \mathrm{L}$, flow rate, $1 \mathrm{~mL} / \mathrm{min}$ with a mobile phase of $\mathrm{H}_{2} \mathrm{O} / \mathrm{MeOH} ; \mathrm{H}_{2} \mathrm{O} / \mathrm{MeOH}=55 / 45$ was initially held for $3 \mathrm{~min}$, followed by a linear gradient from $55 / 45$ to $5 / 95=\mathrm{H}_{2} \mathrm{O} / \mathrm{MeOH}$ over $15 \mathrm{~min}$, which was then held for $12 \mathrm{~min}$.

\subsection{Synthesis of Compound $\mathbf{1 1}$}

A solution of commercially available 4-methoxybenzylchloride 9 (1.0 mmol, $1.0 \mathrm{eq})$, 3,4,5-trimethoxyaniline 10 ( $1.0 \mathrm{mmol}, 1.0 \mathrm{eq}), \mathrm{K}_{2} \mathrm{CO}_{3}(2.0 \mathrm{mmol}, 2.0 \mathrm{eq})$ were added into $20 \mathrm{~mL} \mathrm{DMF}$, and the reaction was stirred for $6 \mathrm{~h}$ at $25^{\circ} \mathrm{C}$. Upon completion, add $15 \mathrm{~mL}$ water and extract aqueous layer three times using ethyl acetate $(20 \mathrm{~mL})$. The collected organic layer was washed with saturated salt water, dried with magnesium sulfate anhy- 
drous and evaporated to get crude product. The crude product was purified by column chromatography to obtain compound $\mathbf{1 1 .}$

\subsection{Synthesis of Compound $\mathbf{1 3}$}

A solution of compound 11 (1.0 mmol, $1.0 \mathrm{eq})$ and chloroacetyl chloride 12 (1.5 mmol, $1.5 \mathrm{eq}$ ) was added into $20 \mathrm{~mL}$ dichloromethane, and the reaction was stirred for $4 \mathrm{~h}$ at $25^{\circ} \mathrm{C}$. Upon completion, organic phase was collected to obtain crude products and then were purified with column chromatography to give compound 13 .

\subsection{Synthesis of Compounds $\mathbf{1 5 a}-\mathbf{h}$}

A solution of compound 13 (1.0 mmol, $1.0 \mathrm{eq})$, substituted indoles, indolines or tetrahydroquinoline 14 (1.5 mmol, $1.5 \mathrm{eq})$ and $\mathrm{K}_{2} \mathrm{CO}_{3}(2.0 \mathrm{mmol}, 2.0 \mathrm{eq})$ were added were $20 \mathrm{~mL}$ acetonitrile, and the reactions were stirred for $8 \mathrm{~h}$ at $80^{\circ} \mathrm{C}$. Upon completion, organic phase was collected to obtain crude products and then were purified with column chromatography to give compound 15a-h.

2-(1H-Indol-1-yl)-N-(4-methoxybenzyl)-N-(3,4,5-trimethoxyphenyl) acetamide (15a). Yield, 47\%, m.p. $162-163{ }^{\circ} \mathrm{C}$, White solid. ${ }^{1} \mathrm{H}$ NMR $\left(400 \mathrm{MHz}, \mathrm{DMSO}-d_{6}\right) \delta 7.52(\mathrm{~d}, J=7.6 \mathrm{~Hz}, 1 \mathrm{H})$, $7.25(\mathrm{~d}, J=8.2 \mathrm{~Hz}, 1 \mathrm{H}), 7.08(\mathrm{ddd}, J=35.7,15.9,8.0 \mathrm{~Hz}, 5 \mathrm{H}), 6.86(\mathrm{~d}, J=8.1 \mathrm{~Hz}, 2 \mathrm{H}), 6.54(\mathrm{~s}$, 2H), $6.39(\mathrm{~s}, 1 \mathrm{H}), 4.81(\mathrm{~d}, J=38.6 \mathrm{~Hz}, 4 \mathrm{H}), 3.69(\mathrm{t}, J=12.8 \mathrm{~Hz}, 12 \mathrm{H}) .{ }^{15} \mathrm{C} \mathrm{NMR}(101 \mathrm{MHz}$, DMSO- $d_{6}$ ) $\delta 167.03,158.48,153.04,157.02,156.27,156.08,129.78,129.62,129.25,127.98$, $120.88,120.16,118.94,115.60,109.70,105.99,100.65,60.00,55.96,55.01,51.86,47.88,40.11$, 39.90, 39.70, 39.49, 39.28, 39.07, 38.86. HR-MS (ESI): Calcd. $\mathrm{C}_{27} \mathrm{H}_{28} \mathrm{~N}_{2} \mathrm{O}_{5},[\mathrm{M}+\mathrm{H}]^{+} m / z$ : 461.2071, found: 461.2074 . HPLC: $t_{\mathrm{R}} 7.06 \mathrm{~min}$, purity $93.97 \%$.

2-(5-Methoxy-1H-indol-1-yl)-N-(4-methoxybenzyl)-N-(3,4,5-trimethoxyphenyl) acetamide (15b). Yield, 50\%, m.p.: $173-174{ }^{\circ} \mathrm{C} .{ }^{1} \mathrm{H}$ NMR $\left(400 \mathrm{MHz}\right.$, DMSO- $\left.d_{6}\right) \delta 7.19-7.09(\mathrm{~m}, 4 \mathrm{H}), 7.03(\mathrm{~d}$, $J=2.3 \mathrm{~Hz}, 1 \mathrm{H}), 6.86(\mathrm{~d}, J=8.5 \mathrm{~Hz}, 2 \mathrm{H}), 6.74(\mathrm{dt}, J=11.9,6.0 \mathrm{~Hz}, 1 \mathrm{H}), 6.52(\mathrm{~s}, 2 \mathrm{H}), 6.30$ $(\mathrm{d}, J=3.0 \mathrm{~Hz}, 1 \mathrm{H}), 4.80(\mathrm{~d}, J=15.3 \mathrm{~Hz}, 2 \mathrm{H}), 4.76(\mathrm{~s}, 2 \mathrm{H}), 3.74(\mathrm{~s}, 3 \mathrm{H}), 3.71(\mathrm{~d}, J=8.6 \mathrm{~Hz}$, 9H), 3.65 (s, 3H). ${ }^{15} \mathrm{C}$ NMR (100 MHz, DMSO- $\left.d_{6}\right) \delta 198.96,168.05,162.86,156.28,152.78$, 149.30, 159.04, 156.65, 153.86, 129.86, 129.24, 128.61, 125.30, 124.70, 124.15, 120.40, 34.84, 30.79. HR-MS (ESI): Calcd. $\mathrm{C}_{28} \mathrm{H}_{30} \mathrm{~N}_{2} \mathrm{O}_{6},[\mathrm{M}+\mathrm{H}]^{+} m / z: 491.2197$, found: 491.2180. HPLC: $t_{R} 7.76$ min, purity $92.32 \%$.

2-(6-Methoxy-1H-indol-1-yl)-N-(4-methoxybenzyl)-N-(3,4,5-trimethoxyphenyl) acetamide (15c). Yield, 38\%, m.p. $146-147{ }^{\circ} \mathrm{C}$, White solid. ${ }^{1} \mathrm{H}$ NMR $\left(400 \mathrm{MHz}\right.$, DMSO- $\left.d_{6}\right) \delta 7.38(\mathrm{~d}$, $J=8.4 \mathrm{~Hz}, 1 \mathrm{H}), 7.14(\mathrm{~d}, J=8.4 \mathrm{~Hz}, 2 \mathrm{H}), 7.02(\mathrm{~d}, J=3.0 \mathrm{~Hz}, 1 \mathrm{H}), 6.86(\mathrm{~d}, J=8.5 \mathrm{~Hz}, 2 \mathrm{H})$, 6.71-6.63 (m, 2H), $6.49(\mathrm{~s}, 2 \mathrm{H}), 6.31(\mathrm{~d}, J=3.0 \mathrm{~Hz}, 1 \mathrm{H}), 4.79(\mathrm{~d}, J=18.2 \mathrm{~Hz}, 4 \mathrm{H}), 3.75(\mathrm{~s}, 3 \mathrm{H})$, $3.72(\mathrm{~s}, 3 \mathrm{H}), 3.68(\mathrm{~s}, 6 \mathrm{H}), 3.64(\mathrm{~s}, 3 \mathrm{H}) .{ }^{15} \mathrm{C}$ NMR $\left(101 \mathrm{MHz}, \mathrm{DMSO}-d_{6}\right) \delta 167.11,158.49,155.43$, $152.99,156.97,156.12,129.78,129.33,128.23,122.11,120.68,115.59,108.78,105.82,100.73$, 93.28, 59.94, 55.88, 55.15, 55.02, 51.86, 47.89. HR-MS (ESI): Calcd. $\mathrm{C}_{28} \mathrm{H}_{30} \mathrm{~N}_{2} \mathrm{O}_{6},[\mathrm{M}+\mathrm{H}]^{+}$ $m / z: 491.2197$, found: 491.2180 . HPLC: $t_{R} 6.73 \mathrm{~min}$, purity $93.22 \%$.

2-(3-Formyl-1H-indol-1-yl)-N-(4-methoxybenzyl)-N-(3,4,5-trimethoxyphenyl) acetamide (15d). Yield, $51 \%$, m.p. $151-152{ }^{\circ} \mathrm{C},{ }^{1} \mathrm{H}$ NMR $\left(400 \mathrm{MHz}\right.$, DMSO-d $\left.d_{6}\right) \delta 9.95(\mathrm{~s}, 1 \mathrm{H}), 8.15(\mathrm{~d}, J=7.3 \mathrm{~Hz}$, $2 \mathrm{H}), 7.49(\mathrm{~d}, J=7.9 \mathrm{~Hz}, 1 \mathrm{H}), 7.38-7.28(\mathrm{~m}, 2 \mathrm{H}), 7.19(\mathrm{~d}, J=8.5 \mathrm{~Hz}, 2 \mathrm{H}), 6.91(\mathrm{~d}, J=8.5 \mathrm{~Hz}$, 2H), $6.63(\mathrm{~s}, 2 \mathrm{H}), 5.07(\mathrm{~s}, 2 \mathrm{H}), 4.83(\mathrm{~s}, 2 \mathrm{H}), 3.77(\mathrm{~s}, 9 \mathrm{H}), 3.72(\mathrm{~s}, 3 \mathrm{H})$. White solid. ${ }^{15} \mathrm{C}$ NMR $\left(101 \mathrm{MHz}\right.$, DMSO- $\left.d_{6}\right) \delta 184.63,166.11,158.53,153.10,142.01,157.66,157.12,155.71,129.83$, 129.06, 124.38, 123.38, 122.35, 120.81, 119.32, 115.61, 111.06, 106.04, 60.00, 55.99, 55.02, 51.99, 48.60. HR-MS (ESI): Calcd. $\mathrm{C}_{28} \mathrm{H}_{28} \mathrm{~N} 2 \mathrm{O} 6,[\mathrm{M}+\mathrm{H}]^{+} m / z: 489.2020$, found: 489.2026. HPLC: $t_{R} 5.01 \mathrm{~min}$, purity $98.91 \%$.

2-(6-Methoxy-1H-indol-1-yl)-N-(4-methoxybenzyl)-N-(3,4,5-trimethoxyphenyl) acetamide (15e). Yield, 38\%, m.p. $162-163{ }^{\circ} \mathrm{C}$, White solid. ${ }^{1} \mathrm{H}$ NMR $\left(400 \mathrm{MHz}\right.$, DMSO- $\left.d_{6}\right) \delta 9.86(\mathrm{~s}, 1 \mathrm{H}), 8.03$ $(\mathrm{s}, 1 \mathrm{H}), 7.59(\mathrm{~d}, J=2.3 \mathrm{~Hz}, 1 \mathrm{H}), 7.34(\mathrm{~d}, J=8.9 \mathrm{~Hz}, 1 \mathrm{H}), 7.14(\mathrm{~d}, J=8.4 \mathrm{~Hz}, 2 \mathrm{H}), 6.96-6.82$ $(\mathrm{m}, 3 \mathrm{H}), 6.57(\mathrm{~s}, 2 \mathrm{H}), 4.99(\mathrm{~s}, 2 \mathrm{H}), 4.78(\mathrm{~s}, 2 \mathrm{H}), 3.80(\mathrm{~s}, 3 \mathrm{H}), 3.72(\mathrm{~d}, J=2.1 \mathrm{~Hz}, 9 \mathrm{H}), 3.67(\mathrm{~s}$, $3 \mathrm{H}), 3.35(\mathrm{~s}, 4 \mathrm{H}) .{ }^{15} \mathrm{C}$ NMR (101 MHz, DMSO- $\left.d_{6}\right) \delta 184.48,166.12,158.52,155.87,153.08$, 
141.94, 157.08, 155.70, 152.54, 129.82, 129.06, 125.15, 119.09, 115.60, 115.02, 111.95, 106.00, 102.61, 59.98, 55.97, 55.35, 55.01, 51.99, 48.78. HR-MS (ESI): Calcd. $\mathrm{C}_{29} \mathrm{H}_{30} \mathrm{~N}_{2} \mathrm{O}_{7},[\mathrm{M}+\mathrm{H}]^{+}$ $m / z$ : 519.2126, found: 519.2151 . HPLC: $t_{R} 4.90 \mathrm{~min}$, purity $92.22 \%$.

2-(3-Formyl-5-methyl-1H-indol-1-yl)-N-(4-methoxybenzyl)-N-(3,4,5-trimethoxyphenyl) acetamide (15f). Yield, 33\%, m.p. $170-171{ }^{\circ} \mathrm{C}$, White solid. ${ }^{1} \mathrm{H}$ NMR (400 MHz, DMSO- $\left.d_{6}\right) \delta 9.86$ $(\mathrm{s}, 1 \mathrm{H}), 8.03(\mathrm{~s}, 1 \mathrm{H}), 7.90(\mathrm{~s}, 1 \mathrm{H}), 7.31(\mathrm{~d}, J=8.3 \mathrm{~Hz}, 1 \mathrm{H}), 7.15(\mathrm{t}, J=7.1 \mathrm{~Hz}, 3 \mathrm{H}), 6.86(\mathrm{~d}$, $J=8.3 \mathrm{~Hz}, 2 \mathrm{H}), 6.57(\mathrm{~s}, 2 \mathrm{H}), 4.98(\mathrm{~s}, 2 \mathrm{H}), 4.77(\mathrm{~s}, 2 \mathrm{H}), 3.69(\mathrm{~d}, J=22.0 \mathrm{~Hz}, 12 \mathrm{H}), 2.42(\mathrm{~s}$, $3 \mathrm{H}) .{ }^{15} \mathrm{C}$ NMR $\left(101 \mathrm{MHz}, \mathrm{DMSO}-d_{6}\right) \delta 184.49,166.14,158.52,153.09,141.96,157.10,156.06$, 155.72, 151.39, 129.82, 129.07, 124.77, 124.63, 120.58, 119.01, 115.60, 110.68, 106.01, 59.99, 55.97, 55.01, 51.98, 48.62, 21.07. HR-MS (ESI): Calcd. $\mathrm{C}_{29} \mathrm{H}_{30} \mathrm{~N}_{2} \mathrm{O}_{6},[\mathrm{M}+\mathrm{Na}]^{+} m / z: 525.1996$, found: 525.2001 . HPLC: $t_{R} 5.74 \mathrm{~min}$, purity $90.88 \%$.

2-(5-Bromoindolin-1-yl)-N-(4-methoxybenzyl)-N-(3,4,5-trimethoxyphenyl) acetamide (15g). Yield, 54\%, m.p. $149-150{ }^{\circ} \mathrm{C}$, White solid. ${ }^{1} \mathrm{H}$ NMR $\left(400 \mathrm{MHz}, \mathrm{DMSO}-d_{6}\right) \delta 7.15-7.01(\mathrm{~m}, 4 \mathrm{H})$, $6.86(\mathrm{~d}, J=8.5 \mathrm{~Hz}, 2 \mathrm{H}), 6.48(\mathrm{~s}, 2 \mathrm{H}), 6.22(\mathrm{~d}, J=8.3 \mathrm{~Hz}, 1 \mathrm{H}), 4.75(\mathrm{~s}, 2 \mathrm{H}), 3.80(\mathrm{~s}, 2 \mathrm{H}), 3.72$ $(\mathrm{s}, 3 \mathrm{H}), 3.67(\mathrm{~s}, 6 \mathrm{H}), 3.63(\mathrm{~s}, 3 \mathrm{H}), 3.43(\mathrm{t}, J=8.5 \mathrm{~Hz}, 2 \mathrm{H}), 2.88(\mathrm{t}, J=8.4 \mathrm{~Hz}, 2 \mathrm{H}) .{ }^{15} \mathrm{C} \mathrm{NMR}$ $\left(101 \mathrm{MHz}, \mathrm{DMSO}-d_{6}\right) \delta 167.83,158.44,152.97,151.05,156.91,156.58,151.87,129.68,129.49$, 129.15, 126.63, 115.61, 107.37, 107.07, 105.84, 60.01, 55.99, 55.02, 52.45, 51.58, 49.22, 27.66. HR-MS (ESI): Calcd. $\mathrm{C}_{27} \mathrm{H}_{29} \mathrm{BrN}_{2} \mathrm{O}_{5},[\mathrm{M}+\mathrm{H}]^{+} \mathrm{m} / z$ : 541.1533, found: 541.1537. HPLC: $t_{R}$ 10.97 min, purity $95.64 \%$.

2-(6-Methoxy-3,4-dihydroquinolin-1(2H)-yl)-N-(4-methoxybenzyl)-N-(3,4,5-trimethoxyphenyl) acetamide (15h). Yield, 32\%, m.p. $139-140{ }^{\circ} \mathrm{C}$, White solid. ${ }^{1} \mathrm{H}$ NMR $\left(400 \mathrm{MHz}, \mathrm{DMSO}-d_{6}\right) \delta$ $7.12(\mathrm{~d}, J=8.4 \mathrm{~Hz}, 2 \mathrm{H}), 6.85(\mathrm{~d}, J=8.5 \mathrm{~Hz}, 2 \mathrm{H}), 6.59-6.45(\mathrm{~m}, 4 \mathrm{H}), 6.23(\mathrm{~d}, J=8.7 \mathrm{~Hz}, 1 \mathrm{H})$, $4.74(\mathrm{~s}, 2 \mathrm{H}), 3.83(\mathrm{~s}, 2 \mathrm{H}), 3.70(\mathrm{~d}, J=15.4 \mathrm{~Hz}, 9 \mathrm{H}), 3.64(\mathrm{~d}, J=6.2 \mathrm{~Hz}, 6 \mathrm{H}), 3.25-3.18(\mathrm{~m}$, 2H), $2.64(\mathrm{t}, J=6.1 \mathrm{~Hz}, 2 \mathrm{H}), 1.83-1.70(\mathrm{~m}, 2 \mathrm{H}) .{ }^{13} \mathrm{C}$ NMR $\left(100 \mathrm{MHz}, \mathrm{DMSO}-d_{6}\right) \delta 169.06$, $158.40,153.00,150.35,139.44,136.87,136.75,129.65,129.62,123.12,114.73,113.56,111.98$, 110.86, 105.61, 60.02, 55.99, 55.23, 55.00, 53.19, 51.49, 49.66, 27.58, 21.92. HR-MS (ESI): Calcd. $\mathrm{C}_{29} \mathrm{H}_{34} \mathrm{~N}_{2} \mathrm{O}_{6},[\mathrm{M}+\mathrm{H}]^{+} m / z: 507.2490$, found: 507.2496. HPLC: $t_{R} 10.97 \mathrm{~min}$, purity $95.64 \%$.

\subsection{Synthesis of Compounds $\mathbf{1 7}$}

A solution of commercially available 3-bromopropyne 16 (1.5 mmol, $1.0 \mathrm{eq})$, indolines or tetrahydroquinoline $14(1.5 \mathrm{mmol}, 1.0 \mathrm{eq})$ and $\mathrm{K}_{2} \mathrm{CO}_{3}(2.0 \mathrm{mmol}, 1.0 \mathrm{eq})$ was added into $20 \mathrm{~mL}$ acetonitrile, and the reactions were stirred for $6 \mathrm{~h}$ at $80^{\circ} \mathrm{C}$. Upon completion, the organic phase was collected to obtain crude products and then were purified with column chromatography to give compounds 17.

\subsection{Synthesis of Compounds $\mathbf{1 8}$}

A solution of compound 13 (1.0 mmol, $1.0 \mathrm{eq})$, sodium azide ( $2.0 \mathrm{mmol}, 2.0 \mathrm{eq})$ and $\mathrm{K}_{2} \mathrm{CO}_{3}(2.0 \mathrm{mmol}, 2.0 \mathrm{eq})$ was added to $20 \mathrm{~mL}$ acetonitrile, and the reactions were stirred for $2 \mathrm{~h}$ at $80^{\circ} \mathrm{C}$. Upon completion, the organic phase was collected to obtain crude products and then were purified with column chromatography to give compound 18.

\subsection{Synthesis of Compounds $19 \mathbf{a}-\mathbf{e}$}

A solution of compound 17 (1.0 mmol, $1.0 \mathrm{eq})$, compounds 18 (1.0 mmol, $1.0 \mathrm{eq})$, $\mathrm{CuSO}_{4}(0.1 \mathrm{mmol}, 0.1 \mathrm{eq})$ and sodium ascorbate $(0.1 \mathrm{mmol}, 0.1 \mathrm{eq})$ was added to $\mathrm{THF} / \mathrm{H}_{2} \mathrm{O}$ $(5 \mathrm{~mL} / 5 \mathrm{~mL})$, and the reactions were stirred for $4 \mathrm{~h}$ at $25^{\circ} \mathrm{C}$. Upon completion, the organic phase was collected to obtain crude products and then were purified with column chromatography to give compounds $19 \mathrm{a}-\mathbf{e}$.

2-(4-((5-Methoxy-1H-indol-1-yl)methyl)-1H-1,2,3-triazol-1-yl)-N-(4-methoxybenzyl)-N-(3,4,5trimethoxyphenyl)acetamide (19a). Yield, $47 \%$, m.p. $158-159{ }^{\circ} \mathrm{C}$, White solid. ${ }^{1} \mathrm{H}$ NMR $\left(400 \mathrm{MHz}, \mathrm{DMSO}-d_{6}\right) \delta 7.85(\mathrm{~s}, 1 \mathrm{H}), 7.46(\mathrm{~d}, J=8.8 \mathrm{~Hz}, 1 \mathrm{H}), 7.38(\mathrm{~s}, 1 \mathrm{H}), 7.12(\mathrm{~d}, J=7.5 \mathrm{~Hz}$, 2H), $7.04(\mathrm{~s}, 1 \mathrm{H}), 6.85(\mathrm{~d}, J=7.6 \mathrm{~Hz}, 2 \mathrm{H}), 6.77(\mathrm{~d}, J=8.9 \mathrm{~Hz}, 1 \mathrm{H}), 6.55(\mathrm{~s}, 2 \mathrm{H}), 6.35(\mathrm{~s}, 1 \mathrm{H})$, $5.43(\mathrm{~s}, 2 \mathrm{H}), 5.08(\mathrm{~s}, 2 \mathrm{H}), 4.76(\mathrm{~s}, 2 \mathrm{H}), 3.74(\mathrm{~s}, 3 \mathrm{H}), 3.70(\mathrm{~d}, J=8.4 \mathrm{~Hz}, 9 \mathrm{H}), 3.65(\mathrm{~s}, 3 \mathrm{H}) .{ }^{15} \mathrm{C}$ 
NMR $\left(101 \mathrm{MHz}, \mathrm{DMSO}-d_{6}\right) \delta 165.65,159.02,154.03,153.55,143.89,157.60,155.94,151.32$, $150.30,129.52,129.41,129.14,125.15,114.10,111.68,111.24,106.56,102.65,101.09,60.49$, $56.45,55.79,55.51,52.33,51.50,41.46$. HR-MS (ESI): Calcd. $\mathrm{C}_{31} \mathrm{H}_{33} \mathrm{~N}_{5} \mathrm{O}_{6},[\mathrm{M}+\mathrm{H}]^{+} \mathrm{m} / z$ : 572.2504, found: 572.2509 . HPLC: $t_{R} 5.29 \mathrm{~min}$, purity $92.17 \%$.

2-(4-((2-Formyl-1H-indol-1-yl)methyl)-1H-1,2,3-triazol-1-yl)-N-(4-methoxybenzyl)-N-(3,4,5trimethoxyphenyl)acetamide (19b). Yield, 47\%, m.p. $168-169{ }^{\circ} \mathrm{C}$, White solid. ${ }^{1} \mathrm{H}$ NMR $\left(400 \mathrm{MHz}, \mathrm{DMSO}-\mathrm{d}_{6}\right) \delta 9.94(\mathrm{~s}, 1 \mathrm{H}), 8.41(\mathrm{~s}, 1 \mathrm{H}), 8.15-8.02(\mathrm{~m}, 2 \mathrm{H}), 7.73(\mathrm{~d}, J=8.0 \mathrm{~Hz}, 1 \mathrm{H})$, $7.29(\mathrm{dd}, J=15.6,7.5 \mathrm{~Hz}, 2 \mathrm{H}), 7.12(\mathrm{~d}, J=8.1 \mathrm{~Hz}, 2 \mathrm{H}), 6.85(\mathrm{~d}, J=8.2 \mathrm{~Hz}, 2 \mathrm{H}), 6.56(\mathrm{~s}$, 2H), $5.64(\mathrm{~s}, 2 \mathrm{H}), 5.11(\mathrm{~s}, 2 \mathrm{H}), 4.77(\mathrm{~s}, 2 \mathrm{H}), 3.69(\mathrm{t}, J=12.0 \mathrm{~Hz}, 12 \mathrm{H}) .{ }^{15} \mathrm{C} \mathrm{NMR}(101 \mathrm{MHz}$, DMSO- $\left.d_{6}\right) \delta 185.20,165.63,159.03,153.58,142.49,141.11,157.64,157.30,155.93,150.32$, $129.40,125.78,125.21,124.08,123.07,121.52,119.90,114.10,111.84,106.57,60.49,56.45,55.50$, 52.37, 51.62, 42.04. HR-MS (ESI): Calcd. $\mathrm{C}_{31} \mathrm{H}_{31} \mathrm{~N}_{5} \mathrm{O}_{6},[\mathrm{M}+\mathrm{H}]^{+} m / z: 592.2167$, found: 592.2192. HPLC: $t_{R} 4.41 \mathrm{~min}$, purity $95.57 \%$.

N-(4-Methoxybenzyl)-2-(4-((2-methylindolin-1-yl)methyl)-1H-1,2,3-triazol-1-yl)-N-(3,4,5trimethoxyphenyl)acetamide (19c). Yield, 39\%, m.p. 171-172 ${ }^{\circ} \mathrm{C},{ }^{1} \mathrm{H}$ NMR $(400 \mathrm{MHz}, \mathrm{DMSO}-$ $\left.d_{6}\right) \delta 7.78(\mathrm{~s}, 1 \mathrm{H}), 7.12(\mathrm{~d}, J=8.5 \mathrm{~Hz}, 2 \mathrm{H}), 6.95(\mathrm{dt}, J=7.2,3.7 \mathrm{~Hz}, 2 \mathrm{H}), 6.85(\mathrm{~d}, J=8.6 \mathrm{~Hz}$, $2 \mathrm{H}), 6.56(\mathrm{dd}, J=15.9,7.6 \mathrm{~Hz}, 4 \mathrm{H}), 5.07(\mathrm{~s}, 2 \mathrm{H}), 4.76(\mathrm{~d}, J=2.5 \mathrm{~Hz}, 2 \mathrm{H}), 4.52(\mathrm{~d}, J=16.0 \mathrm{~Hz}$, $1 \mathrm{H}), 4.25(\mathrm{~d}, J=15.9 \mathrm{~Hz}, 1 \mathrm{H}), 3.70(\mathrm{~d}, J=7.1 \mathrm{~Hz}, 9 \mathrm{H}), 3.65(\mathrm{~s}, 3 \mathrm{H}), 3.02(\mathrm{dd}, J=15.5,8.4 \mathrm{~Hz}$, $1 \mathrm{H}), 1.31(\mathrm{~d}, J=6.1 \mathrm{~Hz}, 3 \mathrm{H}) .{ }^{15} \mathrm{C}$ NMR $\left(101 \mathrm{MHz}, \mathrm{DMSO}-d_{6}\right) \delta 165.73,159.02,153.57,152.02$, $143.18,157.61,156.00,150.29,129.44,129.02,127.53,125.22,124.36,119.69,114.10,107.60$, $106.56,60.49,59.08,56.45,55.50,52.32,51.45,37.08,19.26$. HR-MS (ESI): Calcd. $\mathrm{C}_{31} \mathrm{H}_{35} \mathrm{~N}_{5} \mathrm{O}_{5}$, $[\mathrm{M}+\mathrm{H}]^{+} m / z: 558.2711$, found: 558.2715 . HPLC: $t_{R} 5.19 \mathrm{~min}$, purity $96.55 \%$.

2-(4-(Indolin-1-ylmethyl)-1H-1,2,3-triazol-1-yl)-N-(4-methoxybenzyl)-N-(3,4,5-trimethoxyphenyl) acetamide (19d). Yield, 51\%, m.p. $165-166{ }^{\circ} \mathrm{C}$, White solid. ${ }^{1} \mathrm{H}$ NMR $\left(400 \mathrm{MHz}, \mathrm{DMSO}-d_{6}\right) \delta$ $7.78(\mathrm{~s}, 1 \mathrm{H}), 7.12(\mathrm{~d}, J=8.5 \mathrm{~Hz}, 2 \mathrm{H}), 6.95(\mathrm{dt}, J=7.2,3.7 \mathrm{~Hz}, 2 \mathrm{H}), 6.85(\mathrm{~d}, J=8.6 \mathrm{~Hz}, 2 \mathrm{H}), 6.56$ $(\mathrm{dd}, J=13.9,7.6 \mathrm{~Hz}, 4 \mathrm{H}), 5.07(\mathrm{~s}, 2 \mathrm{H}), 4.76(\mathrm{~d}, J=2.5 \mathrm{~Hz}, 2 \mathrm{H}), 4.52(\mathrm{~d}, J=16.0 \mathrm{~Hz}, 1 \mathrm{H}), 4.25$ $(\mathrm{d}, J=15.9 \mathrm{~Hz}, 1 \mathrm{H}), 3.70(\mathrm{~d}, J=7.1 \mathrm{~Hz}, 9 \mathrm{H}), 3.65(\mathrm{~s}, 3 \mathrm{H}), 3.02(\mathrm{dd}, J=15.5,8.4 \mathrm{~Hz}, 1 \mathrm{H}), 1.31$ $(\mathrm{d}, J=6.1 \mathrm{~Hz}, 3 \mathrm{H}) .{ }^{13} \mathrm{C}$ NMR $\left(101 \mathrm{MHz}, \mathrm{DMSO}-d_{6}\right) \delta 165.23,158.54,153.08,151.49,143.29$, $142.62,157.18,155.51,129.80,129.75,128.94,127.00,124.88,124.20,119.38,115.62,107.39$, $106.10,60.01,55.99,55.02,52.34,51.85,50.97,43.19,27.87$. HR-MS (ESI): Calcd. $\mathrm{C}_{30} \mathrm{H}_{33} \mathrm{~N}_{5} \mathrm{O}_{5}$, $[\mathrm{M}+\mathrm{H}]^{+} m / z: 544.2554$, found: 544.2559 . HPLC: $t_{R} 7.1 \mathrm{~min}$, purity $88.75 \%$.

N-(4-Methoxybenzyl)-2-(4-((6-methyl-3,4-dihydroquinolin-1(2H)-yl)methyl)-1H-1,2,3-triazol-1-yl)$\mathrm{N}-\left(3,4,5\right.$-trimethoxyphenyl)acetamide (19e). Yield, 44\%, m.p. $162-163{ }^{\circ} \mathrm{C}, 1 \mathrm{H} \mathrm{NMR}(400 \mathrm{MHz}$, DMSO-d 6 ) $\delta 7.76(\mathrm{~s}, 1 \mathrm{H}), 7.15(\mathrm{~d}, \mathrm{~J}=8.2 \mathrm{~Hz}, 2 \mathrm{H}), 6.85(\mathrm{~d}, \mathrm{~J}=8.2 \mathrm{~Hz}, 2 \mathrm{H}), 6.75-6.61(\mathrm{~m}$, $3 \mathrm{H}), 6.55(\mathrm{~s}, 2 \mathrm{H}), 5.07(\mathrm{~s}, 2 \mathrm{H}), 4.77(\mathrm{~s}, 2 \mathrm{H}), 4.47(\mathrm{~s}, 2 \mathrm{H}), 3.70(\mathrm{~d}, \mathrm{~J}=7.0 \mathrm{~Hz}, 9 \mathrm{H}), 3.65(\mathrm{~s}, 3 \mathrm{H})$, $3.31-3.26(\mathrm{~m}, 2 \mathrm{H}), 2.62(\mathrm{t}, \mathrm{J}=6.0 \mathrm{~Hz}, 2 \mathrm{H}), 2.10(\mathrm{~s}, 3 \mathrm{H}), 1.90-1.82(\mathrm{~m}, 2 \mathrm{H}) .{ }^{13} \mathrm{C} \mathrm{NMR}(101 \mathrm{MHz}$, DMSO-d $_{6}$ ) $\delta$ 165.75, 159.02, 153.56, 144.07, 142.98, 157.60, 156.00, 150.29, 150.00, 129.44, 127.64, 124.74, 124.57, 122.68, 114.10, 111.87, 106.55, 60.49, 56.45, 55.50, 52.32, 51.44, 49.37, 46.44, 27.89, 22.42, 20.37. HR-MS (ESI): Calcd. $\mathrm{C}_{32} \mathrm{H}_{35} \mathrm{~N}_{5} \mathrm{O}_{5},[\mathrm{M}+\mathrm{Na}]^{+} \mathrm{m} / \mathrm{z}: 594.2687$, found: 594.2691 . HPLC: $t_{R} 9.50 \mathrm{~min}$, purity $86.08 \%$.

\subsection{Cell Culture}

Cells were cultured in RPMI-1640 medium supplemented with $10 \%$ fetal bovine serum (FBS), $100 \mathrm{U} / \mathrm{mL}$ penicillin and $0.1 \mathrm{mg} / \mathrm{mL}$ streptomycin. All the cells were incubated at $37{ }^{\circ} \mathrm{C}$ and $5 \% \mathrm{CO}_{2}$.

\subsection{MTT Assay}

A total of 5000 cells were seeded into 96-well cell culture plates. After $24 \mathrm{~h}$, cells were treated with synthesized compounds. Then, MTT reagent was added $20 \mu \mathrm{L}$ per well after $48 \mathrm{~h}$ treatment with synthesized compounds. Cells were then incubated for $4 \mathrm{~h}$ at $37^{\circ} \mathrm{C}$. Formazan was then dissolved with DMSO. Absorbencies of formazan solution at 
$490 \mathrm{~nm}$ were determined. SPSS version 10.0 was used for $50 \%$ inhibitory concentration $\left(\mathrm{IC}_{50}\right)$ calculation $[41,42]$.

\subsection{Tubulin Polymerization Detection}

Pig brain microtubule protein was isolated by three cycles of temperature-dependent assembly/disassembly in PIPES (pH 6.5, $100 \mathrm{mM}), \mathrm{MgSO}_{4}(1.0 \mathrm{mM})$, EGTA $(2.0 \mathrm{mM}), \mathrm{GTP}$ $(1.0 \mathrm{mM})$ and 2-mercaptoethanol $(1.0 \mathrm{mM})$. In the first cycle of polymerization, glycerol and phenylmethylsulfonyl fluoride were added to $4 \mathrm{M}$ and $0.2 \mathrm{mM}$, respectively. Homogeneous tubulin was prepared from microtubule protein by phosphocellulose (P11) chromatography. The purified proteins were stored in aliquots at $-70^{\circ} \mathrm{C}$.

Re-suspend tubulin in proton exchange membrane buffer (containing $100 \mathrm{mmol} / \mathrm{L}$ PIPES, $1 \mathrm{mmol} / \mathrm{L}$ EGTA, $0.5 \mathrm{mmol} / \mathrm{L} \mathrm{Mgcl}_{2}, 1 \mathrm{mmol} / \mathrm{L} \mathrm{GTP}, 10.2 \%$ glycerol), and the solution was incubated with different concentrations of compound 15b $(10,20 \mu \mathrm{mol} / \mathrm{L})$, colchicine $(3 \mu \mathrm{mol} / \mathrm{L})$, paclitaxel $(3 \mu \mathrm{mol} / \mathrm{L})$ and the carrier DMSO on ice. Using a spectrophotometer to monitor the absorbance of the reaction at $420 \mathrm{~nm}$ (excitation wavelength is $340 \mathrm{~nm}$ ) [43].

\subsection{Cellular Thermal Shift Assay}

Inoculate the cells in a petri dish, and collect the cells when the cells grow to $90 \%$. The cells were re-suspended in PBS containing phosphatase inhibitor and protease inhibitor, and the cells were repeatedly frozen and thawed in liquid nitrogen. Compound $\mathbf{1 5 b}$ $(100 \mu \mathrm{mol} / \mathrm{L})$ and the same amount of DMSO were added to the protein respectively, and the mixture was heated at $50{ }^{\circ} \mathrm{C}, 55^{\circ} \mathrm{C}, 60{ }^{\circ} \mathrm{C}, 65^{\circ} \mathrm{C}$ and $70{ }^{\circ} \mathrm{C}$ for three times. The supernatant was centrifuged at $15,000 \times g \mathrm{rpm}$, and the sample was used for western blot analysis.

\subsection{EBI Competition Experiment}

In total, $3 \times 10^{5}$ MGC-903 cells ells were seeded into 6-well cell culture plates and cultured for $24 \mathrm{~h}$, incubated with different concentrations of compound $\mathbf{1 5 b}$, colchicine, paclitaxel, and DMSO for $2 \mathrm{~h}$, and then treated with $100 \mu \mathrm{mol} / \mathrm{L} \mathrm{EBI}$ for $1.5 \mathrm{~h}$. The cells were collected, and the $\beta$-tubulin and $\beta$-tubulin adducts were determined with anti- $\beta$-tubulin antibody.

\subsection{Immunofluorescence Experiment}

MGC-803 cells were seeded in 96-well plates and treated with different concentrations of compound $\mathbf{1 5 b}$ for $24 \mathrm{~h}$. Fix the cells with $4 \%$ paraformaldehyde for $10 \mathrm{~min}$, and then infiltrate the cells with PBS containing 0.1\% Triton X-100. After blocking with 5\% BSA at room temperature for $1 \mathrm{~h}$, incubate overnight with anti- $\beta$-tubulin antibody at $4{ }^{\circ} \mathrm{C}$, stain with fluorescent antibody, and label cell nuclei with DAPI. Observe the cells using a fluorescence microscope.

\subsection{Molecular Docking}

The molecular docking study was performed using MOE 2015.10. The crystal structure of tubulin (PDB ID: 1SA0) was retrieved from RCSB Protein Data Bank (https:/ / www.rcsb. org/structure/1SA0, accessed on 1 July 2021), and then was prepared by adding hydrogen atoms, removing water molecules and repairing the missing side chains. The protonation states of protein residues were calculated in the $\mathrm{pKa}$ at 7 . The ligand compound $\mathbf{1 5 b}$ was built in Autodock software (Scripps Research Institute, La Jolla, CA, USA) and was prepared by energy minimization and conformational search. The ligand was docked into the colchicine binding site of tubulin and 20 poses were exported for the next analysis.

\section{Conclusions}

Tubulin has been regarded as an attractive and successful molecular target in cancer therapy and drug discovery. However, owing to the poor water solubility, drug resistance 
and side effects of clinical tubulin inhibitors, it is necessary to develop novel tubulin inhibitors. As the continuation of our group work on colchicine binding-site tubulin inhibitors, we designed and synthesized a series of diarylamide indole derivatives by the combination of vicinal diaryl core and indole skeleton into one hybrid though proper linkers. Among of these compounds, compound $\mathbf{1 5 b}$ exhibited the most potent inhibitory activity against the tested three human cancer cell lines (MGC-803, PC-3 and EC-109) with $\mathrm{IC}_{50}$ values of $1.56 \mu \mathrm{M}, 3.56 \mu \mathrm{M}$ and $14.5 \mu \mathrm{M}$, respectively. Besides, the SARs of these compounds were preliminarily studied and summarized. The most active compound $\mathbf{1 5 b}$ produced the inhibition of tubulin polymerization in a dose-dependent manner and caused microtubule network disruption in MGC-803 cells. Therefore, compound $\mathbf{1 5 b}$ was identified as a novel tubulin polymerization inhibitor targeting the colchicine binding site. In addition, the results of molecular docking also suggested compound $\mathbf{1 5 b}$ tightly bind into the colchicine binding site of $\beta$-tubulin.

Supplementary Materials: The following are available.

Author Contributions: S.-Y.Z. and J.S. designed the research and contributed to revision of manuscript; X.-J.P., G.-X.Y., Y.-B.Z. performed the synthetic work. X.L., Y.L., W.-B.L., Y.-R.L. were responsible for the direction of the biological research; X.L. and X.-J.P. contributed to writing of the manuscript. All authors have read and agreed to the published version of the manuscript.

Funding: This research was funded by the National Natural Sciences Foundations of China (No. 81903541, U2004123 for Sai-Yang Zhang and No. 81673322 for Yan-Bing Zhang) and China Postdoctoral Science Foundation (No. 2019M632812 for Sai-Yang Zhang) and the Henan Scientific Innovation Talent Team, Department for Education (No. 19ITSTHN001 for Wen Zhao, China). Henan Association of Science and Technology (No. 2020HYTP056 for Sai-Yang Zhang, China) and Science and Technology Department of Henan Province (No. 20202310144, for Sai-Yang Zhang, China). The open fund of state key laboratory of Pharmaceutical Biotechnology, Nan-jing University, China (Grant no. KF-GN-202101).

Conflicts of Interest: The authors declare no conflict of interest.

Sample Availability: Samples of the compounds are not available from the authors.

\section{References}

1. Howard, J.; Hyman, A. Dynamics and mechanics of the microtubule plus end. Nat. Cell Biol. 2003, 422, 753-758. [CrossRef]

2. Jordan, M.A.; Wilson, L. Microtubules as a target for anticancer drugs. Nat. Rev. Cancer 2004, 4, 253-265. [CrossRef] [PubMed]

3. Binarová, P.; Tuszynski, J. Tubulin: Structure, Functions and Roles in Disease. Cells 2019, 8, 1294. [CrossRef] [PubMed]

4. Borisy, G.; Heald, R.; Howard, J.; Janke, C.; Musacchio, A.; Nogales, E. Microtubules: 50 years on from the discovery of tubulin. Nat. Rev. Mol. Cell Biol. 2016, 17, 322-328. [CrossRef]

5. Perez, E.A.; Shang, X.; Burlingame, S.M.; Okcu, M.F.; Ge, N.; Russell, H.V.; Egler, R.A.; David, R.D.; Vasudevan, S.A.; Yang, J.; et al. Microtubule inhibitors: Differentiating tubulin-inhibiting agents based on mechanisms of action, clinical activity, and resistance. Mol. Cancer Ther. 2009, 8, 2086-2095. [CrossRef]

6. Kavallaris, M. Microtubules and resistance to tubulin-binding agents. Nat. Rev. Cancer 2010, 10, 194-204. [CrossRef]

7. Bumbaca, B.; Li, W. Taxane resistance in castration-resistant prostate cancer: Mechanisms and therapeutic strategies. Acta Pharm. Sin. B 2018, 8, 518-529. [CrossRef]

8. Lu, Y.; Chen, J.; Xiao, M.; Li, W.; Miller, D.D. An Overview of Tubulin Inhibitors That Interact with the Colchicine Binding Site. Pharm. Res. 2012, 29, 2943-2971. [CrossRef] [PubMed]

9. Tangutur, A.D.; Kumar, D.; Krishna, K.V.; Kantevari, S. Microtubule Targeting Agents as Cancer Chemotherapeutics: An Overview of Molecular Hybrids as Stabilizing and Destabilizing Agents. Curr. Top. Med. Chem. 2017, 17, 2523-2537. [CrossRef]

10. Ramajayam, R. Medicinal chemistry of vicinal diaryl scaffold: A mini review. Eur. J. Med. Chem. 2019, 162, 1-17. [CrossRef]

11. Karatoprak, G.Ş.; Akkol, E.K.; Genç, Y.; Bardakci, H.; Yücel, Ç.; Sobarzo-Sánchez, E. Combretastatins: An Overview of Structure, Probable Mechanisms of Action and Potential Applications. Molecules 2020, 25, 2560. [CrossRef]

12. Hamze, A.; Alami, M.; Provot, O. Developments of isoCombretastatin A-4 derivatives as highly cytotoxic agents. Eur. J. Med. Chem. 2020, 190, 112110. [CrossRef] [PubMed]

13. Bukhari, S.N.A.; Kumar, G.B.; Revankar, H.M.; Qin, H.-L. Development of combretastatins as potent tubulin polymerization inhibitors. Bioorg. Chem. 2017, 72, 130-147. [CrossRef]

14. Pettit, G.R.; Singh, S.B.; Hamel, E.; Lin, C.M.; Alberts, D.S.; Garcia-Kendal, D. Isolation and structure of the strong cell growth and tubulin inhibitor combretastatin A-4. Cell. Mol. Life Sci. 1989, 45, 209-211. [CrossRef]

15. Tron, G.C.; Pirali, T.; Sorba, G.; Pagliai, F.; Busacca, A.S.; Genazzani, A. Medicinal Chemistry of Combretastatin A4: Present and Future Directions. J. Med. Chem. 2006, 49, 3033-3044. [CrossRef] [PubMed] 
16. Kirwan, I.G.; Loadman, P.M.; Swaine, D.J.; Anthoney, D.A.; Pettit, G.R.; Lippert, J.W.; Shnyder, S.; Cooper, P.A.; Bibby, M.C. Comparative Preclinical Pharmacokinetic and Metabolic Studies of the Combretastatin Prodrugs Combretastatin A4 Phosphate and A1 Phosphate. Clin. Cancer Res. 2004, 10, 1446-1453. [CrossRef] [PubMed]

17. Li, L.; Jiang, S.; Li, X.; Liu, Y.; Su, J.; Chen, J. Recent advances in trimethoxyphenyl (TMP) based tubulin inhibitors targeting the colchicine binding site. Eur. J. Med. Chem. 2018, 151, 482-494. [CrossRef] [PubMed]

18. Li, Q.; Jian, X.-E.; Chen, Z.-R.; Chen, L.; Huo, X.-S.; Li, Z.-H.; You, W.-W.; Rao, J.-J.; Zhao, P.-L. Synthesis and biological evaluation of benzofuran-based 3,4,5-trimethoxybenzamide derivatives as novel tubulin polymerization inhibitors. Bioorganic Chem. 2020, 102, 104076. [CrossRef] [PubMed]

19. O’Boyle, N.M.; Pollock, J.K.; Carr, M.; Knox, A.J.S.; Nathwani, S.M.; Wang, S.; Caboni, L.; Zisterer, D.M.; Meegan, M.J. $\beta$-Lactam Estrogen Receptor Antagonists and a Dual-Targeting Estrogen Receptor/Tubulin Ligand. J. Med. Chem. 2014, 57, 9370-9382. [CrossRef] [PubMed]

20. Fu, D.-J.; Li, P.; Wu, B.-W.; Cui, X.-X.; Zhao, C.-B.; Zhang, S.-Y. Molecular diversity of trimethoxyphenyl-1,2,3-triazole hybrids as novel colchicine site tubulin polymerization inhibitors. Eur. J. Med. Chem. 2019, 165, 309-322. [CrossRef] [PubMed]

21. Fu, D.-J.; Yang, J.-J.; Li, P.; Hou, Y.-H.; Huang, S.-N.; Tippin, M.A.; Pham, V.; Song, L.; Zi, X.; Xue, W.-L.; et al. Bioactive heterocycles containing a 3,4,5-trimethoxyphenyl fragment exerting potent antiproliferative activity through microtubule destabilization. Eur. J. Med. Chem. 2018, 157, 50-61. [CrossRef]

22. Song, J.; Gao, Q.-L.; Wu, B.-W.; Zhu, T.; Cui, X.-X.; Jin, C.-J.; Wang, S.-Y.; Wang, S.-H.; Fu, D.-J.; Liu, H.-M.; et al. Discovery of tertiary amide derivatives incorporating benzothiazole moiety as anti-gastric cancer agents in vitro via inhibiting tubulin polymerization and activating the Hippo signaling pathway. Eur. J. Med. Chem. 2020, 203, 112618. [CrossRef] [PubMed]

23. Cushman, M.; He, H.M.; Lin, C.M.; Hamel, E. Synthesis and evaluation of a series of benzylaniline hydrochlorides as potential cytotoxic and antimitotic agents acting by inhibition of tubulin polymerization. J. Med. Chem. 1993, 36, 2817-2821. [CrossRef] [PubMed]

24. Romagnoli, R.; Baraldi, P.G.; Cruz-Lopez, O.; Cara, C.L.; Carrion, M.D.; Brancale, A.; Hamel, E.; Chen, L.; Bortolozzi, R.; Basso, G.; et al. Synthesis and Antitumor Activity of 1,5-Disubstituted 1,2,4-Triazoles as Cis-Restricted Combretastatin Analogues. J. Med. Chem. 2010, 53, 4248-4258. [CrossRef]

25. O’Boyle, N.M.; Carr, M.; Greene, L.M.; Bergin, O.; Nathwani, S.M.; McCabe, T.; Lloyd, D.G.; Zisterer, D.; Meegan, M.J. Synthesis and Evaluation of Azetidinone Analogues of Combretastatin A-4 as Tubulin Targeting Agents. J. Med. Chem. 2010, 53, 8569-8584. [CrossRef] [PubMed]

26. Akhtar, J.; Khan, A.A.; Ali, Z.; Haider, R.; Yar, M.S. Structure-activity relationship (SAR) study and design strategies of nitrogencontaining heterocyclic moieties for their anticancer activities. Eur. J. Med. Chem. 2017, 125, 143-189. [CrossRef] [PubMed]

27. Dhuguru, J.; Skouta, R. Role of Indole Scaffolds as Pharmacophores in the Development of Anti-Lung Cancer Agents. Molecules 2020, 25, 1615. [CrossRef] [PubMed]

28. Kode, J.; Kovvuri, J.; Nagaraju, B.; Jadhav, S.; Barkume, M.; Sen, S.; Kasinathan, N.K.; Chaudhari, P.; Mohanty, B.S.; Gour, J.; et al. Synthesis, biological evaluation, and molecular docking analysis of phenstatin based indole linked chalcones as anticancer agents and tubulin polymerization inhibitors. Bioorg. Chem. 2020, 105, 104447. [CrossRef] [PubMed]

29. Hwang, D.-J.; Wang, J.; Li, W.; Miller, D.D. Structural Optimization of Indole Derivatives Acting at Colchicine Binding Site as Potential Anticancer Agents. ACS Med. Chem. Lett. 2015, 6, 993-997. [CrossRef] [PubMed]

30. Wang, G.; Li, C.; He, L.; Lei, K.; Wang, F.; Pu, Y.; Yang, Z.; Cao, D.; Ma, L.; Chen, J.; et al. Design, synthesis and biological evaluation of a series of pyrano chalcone derivatives containing indole moiety as novel anti-tubulin agents. Bioorg. Med. Chem. 2014, 22, 2060-2079. [CrossRef] [PubMed]

31. Li, W.; Shuai, W.; Sun, H.; Xu, F.; Bi, Y.; Xu, J.; Ma, C.; Yao, H.; Zhu, Z.; Xu, S. Design, synthesis and biological evaluation of quinoline-indole derivatives as anti-tubulin agents targeting the colchicine binding site. Eur. J. Med. Chem. 2019, 163, 428-442. [CrossRef] [PubMed]

32. Ren, Y.; Wang, Y.; Li, G.; Zhang, Z.; Ma, L.; Cheng, B.; Chen, J. Discovery of Novel Benzimidazole and Indazole Analogues as Tubulin Polymerization Inhibitors with Potent Anticancer Activities. J. Med. Chem. 2021, 64, 4498-4515. [CrossRef] [PubMed]

33. Lai, M.-J.; Ojha, R.; Lin, M.-H.; Liu, Y.-M.; Lee, H.-Y.; Lin, T.E.; Hsu, K.-C.; Chang, C.-Y.; Chen, M.-C.; Nepali, K.; et al. 1-Arylsulfonyl indoline-benzamides as a new antitubulin agents, with inhibition of histone deacetylase. Eur. J. Med. Chem. 2019, 162, 612-630. [CrossRef]

34. Yang, J.; Zhou, S.; Ji, L.; Zhang, C.; Yu, S.; Li, Z.; Meng, X. Synthesis and structure-activity relationship of 4-azaheterocycle benzenesulfonamide derivatives as new microtubule-targeting agents. Bioorg. Med. Chem. Lett. 2014, 24, 5055-5058. [CrossRef] [PubMed]

35. Chang, J.-Y.; Hsieh, H.-P.; Chang, C.-Y.; Hsu, K.-S.; Chiang, Y.-F.; Chen, C.-M.; Kuo, A.C.-C.; Liou, J.-P. 7-Aroyl-aminoindoline-1sulfonamides as a Novel Class of Potent Antitubulin Agents. J. Med. Chem. 2006, 49, 6656-6659. [CrossRef]

36. Wang, X.-F.; Guan, F.; Ohkoshi, E.; Guo, W.; Wang, L.; Zhu, D.-Q.; Wang, S.-B.; Wang, L.-T.; Hamel, E.; Yang, D.; et al. Optimization of 4-(N-Cycloamino)phenylquinazolines as a Novel Class of Tubulin-Polymerization Inhibitors Targeting the Colchicine Site. J. Med. Chem. 2014, 57, 1390-1402. [CrossRef] [PubMed]

37. Wang, X.-F.; Wang, S.-B.; Ohkoshi, E.; Wang, L.-T.; Hamel, E.; Qian, K.; Morris-Natschke, S.L.; Lee, K.-H.; Xie, L. N-Aryl-6methoxy-1,2,3,4-tetrahydroquinolines: A novel class of antitumor agents targeting the colchicine site on tubulin. Eur. J. Med. Chem. 2013, 67, 196-207. [CrossRef] [PubMed] 
38. Banerjee, S.; Arnst, K.E.; Wang, Y.; Kumar, G.; Deng, S.; Yang, L.; Li, G.-B.; Yang, J.; White, S.W.; Li, W.; et al. Heterocyclic-Fused Pyrimidines as Novel Tubulin Polymerization Inhibitors Targeting the Colchicine Binding Site: Structural Basis and Antitumor Efficacy. J. Med. Chem. 2018, 61, 1704-1718. [CrossRef]

39. Sung, H.; Ferlay, J.; Siegel, R.L.; Laversanne, M.; Soerjomataram, I.; Jemal, A.; Bray, F. Global cancer statistics 2020: GLOBOCAN estimates of incidence and mortality worldwide for 36 cancers in 185 countries. CA Cancer J. Clin. 2021, 71, 209-249. [CrossRef]

40. Xu, Z.; Zhao, S.-J.; Liu, Y. 1,2,3-Triazole-containing hybrids as potential anticancer agents: Current developments, action mechanisms and structure-activity relationships. Eur. J. Med. Chem. 2019, 183, 111700. [CrossRef]

41. Song, J.; Gao, Q.-L.; Wu, B.-W.; Li, D.; Shi, L.; Zhu, T.; Lou, J.-F.; Jin, C.-Y.; Zhang, Y.-B.; Zhang, S.-Y.; et al. Novel tertiary sulfonamide derivatives containing benzimidazole moiety as potent anti-gastric cancer agents: Design, synthesis and SAR studies. Eur. J. Med. Chem. 2019, 183, 111731. [CrossRef] [PubMed]

42. Song, J.; Cui, X.-X.; Wu, B.-W.; Li, D.; Wang, S.-H.; Shi, L.; Zhu, T.; Zhang, Y.-B.; Zhang, S.-Y. Discovery of 1,2,4-triazine-based derivatives as novel neddylation inhibitors and anticancer activity studies against gastric cancer MGC-803 cells. Bioorg. Med. Chem. Lett. 2020, 30, 126791. [CrossRef] [PubMed]

43. Zhu, T.; Wang, S.-H.; Li, D.; Wang, S.-Y.; Liu, X.; Song, J.; Wang, Y.-T.; Zhang, S.-Y. Progress of tubulin polymerization activity detection methods. Bioorg. Med. Chem. Lett. 2021, 37, 127698. [CrossRef] [PubMed] 